\title{
ISOTHERMAL MASS EXCHANGE IN INHOMOGENEOUS POROUS ADSORBENT GRANULES WITH A SEQUENTIAL MACRO- AND MICRODIFFUSION TRANSFER MECHANISM
}

\author{
A. V. Ryazhskih ${ }^{1}$, ryazhskihav@bk.ru, \\ A. V. Keller ${ }^{1}$, alevtinak@inbox.ru, \\ A. V. Khorvat ${ }^{2}$, alexey-khorvat@yandex.ru, \\ A. S. Vikulin ${ }^{2}$, mmiler5472@yandex.ru, \\ V. I. Ryazhskih ${ }^{1}$, ryazhskih_vi@mail.ru. \\ ${ }^{1}$ Voronezh State Technical University, Voronezh, Russian Federation, \\ ${ }^{2}$ Military Educational and Scientific Center of the Air Force "N. E. Zhukovsky and \\ Y. A. Gagarin Air Force Academy", Voronezh, Russian Federation
}

In the 1-D format, the problem of nonstationary isothermal local distribution of a diffusing single-species substance in successively located axisymmetric spherical regions of a granule with different permeabilities of macro- and micropores is formulated. The initial-boundary value problem for a system of differential equations of parabolic type with a boundary condition of the first kind on the outer boundary of a granule and of the fourth kind on the boundary of conjugation of the domains is integrated numerically. A computational experiment has demonstrated the influence of the regions permeability and the dislocation of the boundary between them on the kinetics of material transport.

Keywords: mass transfer; adsorbent granules; heterogeneity; diffusion.

\section{Introduction}

The analysis of the adsorption kinetics on the scale of an adsorbent granule, as a rule, is based on the assumption that its internal structure is pseudo-uniform [1]. However, this approach negates the possibility of assessing effect of different-permeable regions dislocation on the absorption rate of adsorbents by the intragranular space [2]. This circumstance is taken into account by the pre-selected topology of the granule regions arrangement: sequential, parallel, mixed, randomly distributed [3]. In general, this problem is solved so far only with the help of an experimental approach [4]. The topology of the sequential arrangement of differently permeable regions is considered under the condition of additional assumptions, the main ones of which are [5]: granules sphericity and arrangement axisymmetry of bidisperse inhomogeneities associated with diffusion transfer mechanisms in macro- and micropores; spatial one-dimensionality; constancy of physical and chemical parameters; isometric; perfect contact at the border of the mating areas. A simplified mathematical formulation is represented as a system of parabolic equations in a 1-D spherical coordinate system [6]:

$$
\begin{gathered}
\frac{\partial c_{m}(r, \tau)}{\partial \tau}=\frac{1}{r^{2}} \frac{\partial}{\partial r}\left[D_{m} r^{2} \frac{\partial c_{m}(r, \tau)}{\partial r}\right], 0 \leq r<r_{m} \\
\frac{\partial c_{M}(r, \tau)}{\partial \tau}=\frac{1}{r^{2}} \frac{\partial}{\partial r}\left[D_{M} r^{2} \frac{\partial c_{M}(r, \tau)}{\partial r}\right], r_{m} \leq r \leq r_{M}
\end{gathered}
$$


with initial boundary condition

$$
c_{m}(r, 0)=c_{M}(r, 0)=c_{0}
$$

of the first kind on the surface of the granule

$$
c_{M}\left(r_{M}, \tau\right)=c_{s}
$$

boundary conditions of the fourth kind, reflecting the perfect contact between regions of different permeability

$$
\begin{aligned}
c_{m}\left(r_{m}, \tau\right) & =c_{M}\left(r_{m}, \tau\right) ; \\
D_{m} \frac{\partial c_{m}\left(r_{m}, \tau\right)}{\partial r} & =D_{M} \frac{\partial c_{M}\left(r_{m}, \tau\right)}{\partial r}
\end{aligned}
$$

with the additional condition of boundedness at the point of symmetry

$$
c_{m}(0, \tau) \neq \infty
$$

where $\tau$ is time; $\mathrm{r}$ - current radial coordinate; $c_{M}, c_{m}$ - local concentrations of adsorbate in areas of different permeability $0 \leq r<r_{m}$ and $r_{m} \leq r \leq r_{M}$, accordingly; $c_{0}=$ const - the concentration of the adsorbent on the granule surface; , $D_{M}, D_{m}$-diffusion coefficients in areas $0 \leq r<r_{m}$ and $r_{m} \leq r \leq r_{M} ; r_{m} ; r_{m}$ - radius of the contact surface of the regions; $r_{M}$ is the granule radius.

\section{Numerical Scheme}

System (1)-(7), represented in dimensionless form using relative variables

$$
\begin{gathered}
\theta=\tau D_{m} / r_{m}^{2} ; R=r / r_{m} ; D=D_{M} / D_{m} ; \\
C_{m, M}(R, \theta)=\left[c_{m, M}(r, \tau)-c_{0}\right] /\left(c_{s}-c_{0}\right) ; \eta=r_{M} / r_{m} ; \\
\frac{\partial\left[R C_{m}(R, \theta)\right]}{\partial \theta}=\frac{\partial^{2}\left[R C_{m}(R, \theta)\right]}{\partial R^{2}}, 0 \leq R<1 ; \\
\frac{\partial\left[R C_{M}(R, \theta)\right]}{\partial \theta}=D \frac{\partial^{2}\left[R C_{M}(R, \theta)\right]}{\partial R^{2}}, 1 \leq R \leq \eta ; \\
C_{m}(R, 0)=C_{M}(R, 0)=0 ; \\
C_{M}(\eta, \theta)=1 ; \\
C_{m}(1, \theta)=C_{M}(1, \theta) ; \\
\frac{\partial C_{m}(1, \theta)}{\partial R}=D \frac{\partial C_{M}(1, \theta)}{\partial R} ; \\
C_{m}(0, \theta) \neq \infty
\end{gathered}
$$

is integrated numerically on a uniform grid of the definition domain according to the +-shaped template (Fig. 1). 


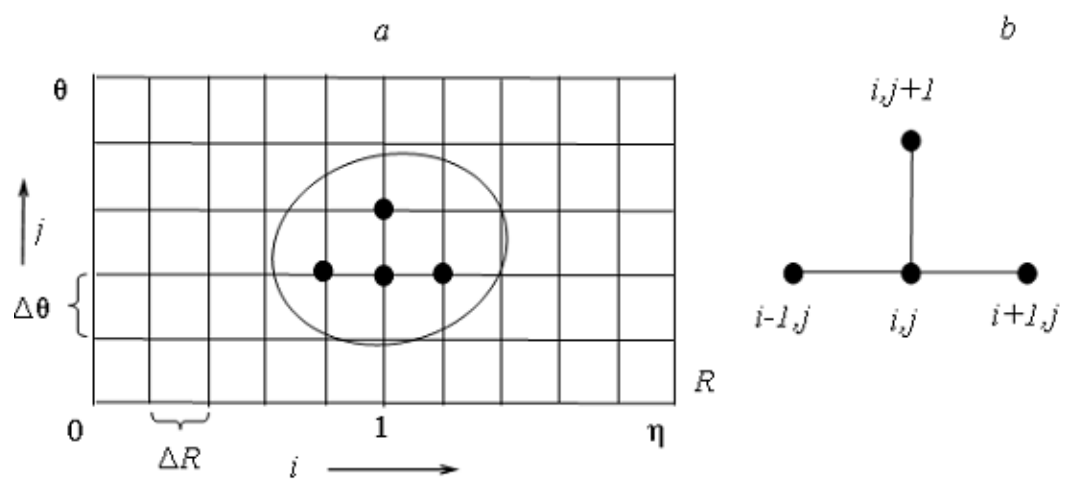

Fig. 1. Discretization of the integration domain (a) and a template for constructing a finitedifference scheme (b)

The finite-difference analogue (8)-(14) is represented by an explicit scheme for the exact function $C_{m, M}^{i, j}=C_{m, M}(i \Delta R, j \Delta \theta)$ :

$$
\begin{gathered}
C_{m}^{i, j+1}=A_{m}^{i} C_{m}^{i+1, j}+B_{m} C_{m}^{i, j}+C_{m}^{i} C_{m}^{i-1, j} \\
C_{M}^{i, j+1}=A_{M}^{i} C_{M}^{i+1, j}+B_{M} C_{M}^{i, j}+C_{M}^{i} C_{M}^{i-1, j} ; \\
C_{m}^{i, 0}=0, i=\overline{1, M 1} ; C_{M}^{i, 0}=0, i=\overline{M 1+1, M} \\
C_{M}^{M+1, j}=0 ; j=\overline{0, N} \\
C_{m}^{M 1, j}=C_{M}^{M 1, j} ; j=\overline{0, N} ; \\
C_{m}^{M 1, j}={ }_{-}\left(4 C_{M}^{M 1+1, j}-C_{M}^{M 1+2, j}+4 C_{m}^{M 1-1, j-1}-C_{m}^{M 1-2, j-1}\right) /[3(D+1)], j=\overline{0, N} \\
C_{m}^{1, j}={ }_{-}\left(4 C_{m}^{2, j}-C_{m}^{3, j}\right) / 3, j=\overline{0, N}
\end{gathered}
$$

where

$$
\begin{gathered}
A_{m}^{i}=\Delta \theta\left(1+i^{-1}\right) / \Delta R^{2} ; B_{m}=1-2 \Delta \theta / \Delta R^{2} ; C_{m}^{i}=\Delta \theta\left(1-i^{-1}\right) / \Delta R^{2} ; \\
A_{M}^{i}=D A_{m}^{i} ; B_{M}=1-2 D \Delta \theta / \Delta R^{2} ; C_{M}^{i}=D C_{m}^{i} ;
\end{gathered}
$$

$\Delta R=\eta / M(M-$ the segments number of the region partition $R) ; \Delta \theta=\varepsilon \Delta R(\varepsilon \ll 1$, is selected $\varepsilon=0,01) ; M 1$ - node number in $R$ corresponding to coordinate $R=1 ; N$ - finite value of the steps number in dimensionless time.

\section{Computational Experiment}

The calculation results (Fig. 2) show that at $D>1$, the matter transfer is more intense than at $D<1$ (i.e., the permeability of the granule core limits the kinetics). If the granule dislocation between the regions is shifted towards the granule center, then the absorption kinetics also tends to decrease.

\section{Conclusion}

A toolkit has been developed for assessing the kinetics of intragranular adsorbate absorption taking into account the adsorbent structure with a sequential arrangement of regions of different permeability in the isothermal regime. 


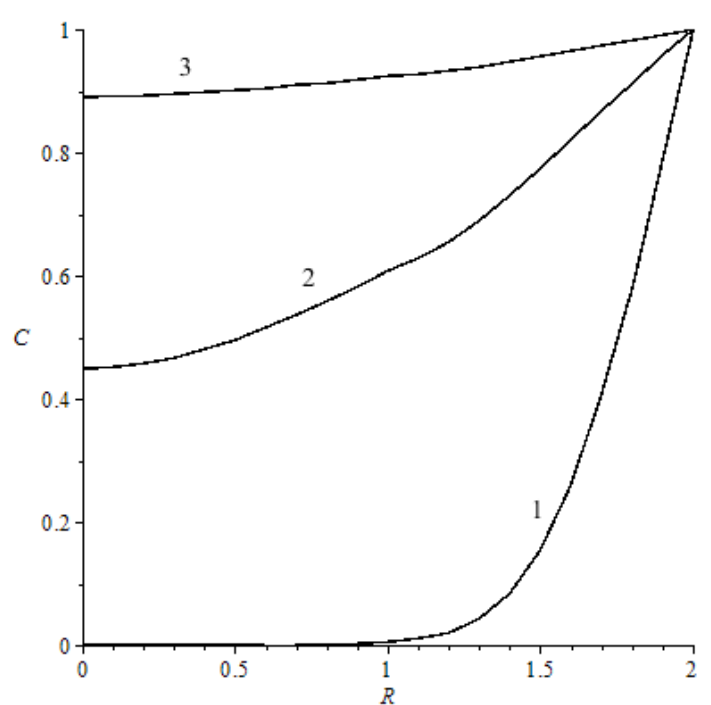

a

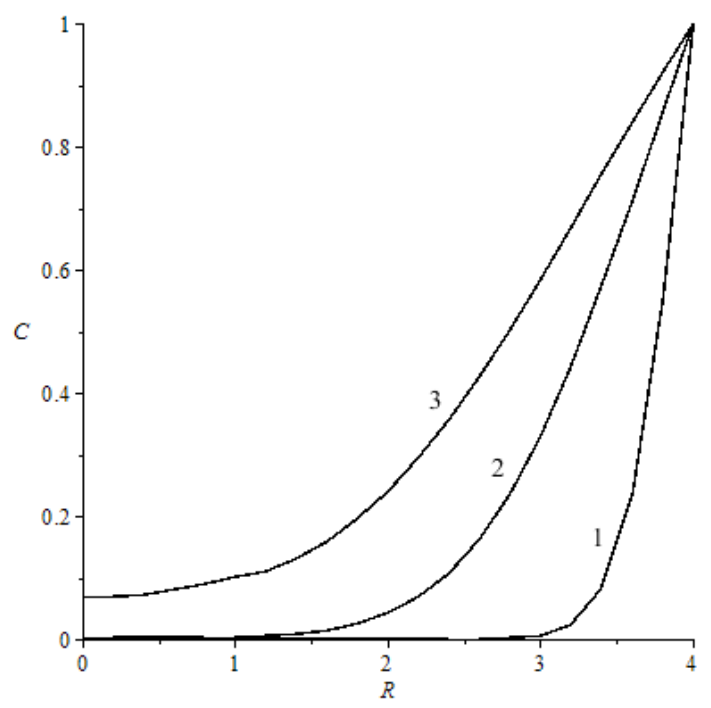

$\mathrm{C}$

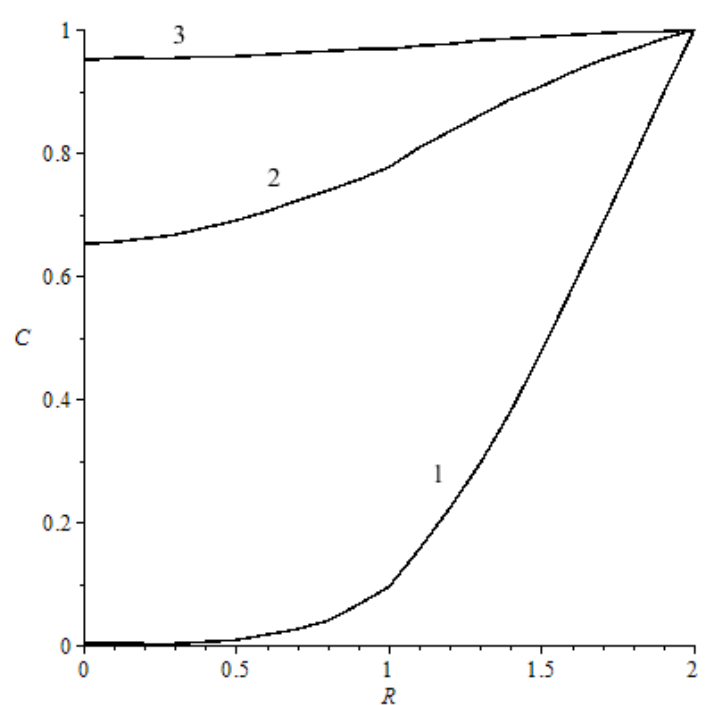

$\mathrm{b}$

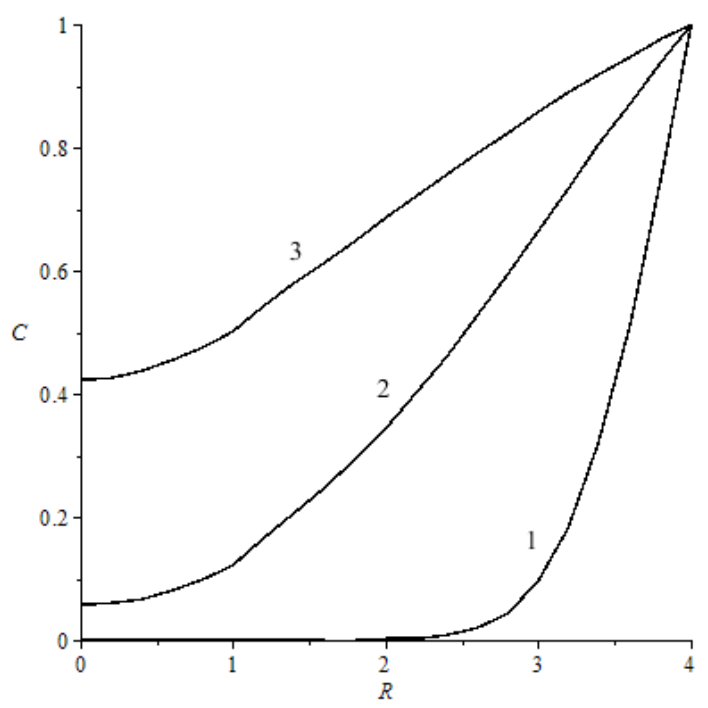

$\mathrm{d}$

Fig. 2. Local concentration fields at: $a-D=0.5 ; \eta=2 ; \quad b-D=1.5 ; \eta=2 ; c-D=0.5$; $\eta=4 ; \quad d-D=1.5 ; \eta=4$ at various moments of dimensionless time $\theta: 1-0.1 ; 2-0.75 ; 3-1.7$

\section{References}

1. Inglezakis V. J., Fyrillas M. M., Park J. Variable Diffusivity Homogeneous Surface Diffusion Model and Analysis of Merits and Fallacies of Simplified Adsorption Kinetics Equations. Journal of Hazardous Materials, 2018, vol. 367, pp. 224-245. DOI: $10.1016 /$ j.jhazmat.2018.12.023

2. Tien C. Introductions to Adsorption: Basic, Analysis and Applications. N. Y., Elsevier, 2018.

3. Suzuki M. Adsorption Engineering. Tokyo, Kodansha Ltd, 1990.

4. Toth J. Adsorption: Theory, Modeling, and Analysis. N. Y., Marcel Dekker, 2001. 
5. Tovbin Y.K. The Molecular Theory of Adsorption in Porous Solid. N. Y., CRC Press, 2017.

6. Tien C. Adsorption calculations and modeling. Boston, Butter-Heinemann, 1994.

Alexander V. Ryazhskih, PhD (Math), Docent, Associate Professor at the Department of Applied Mathematics and Mechanics, Voronezh State Technical University (Voronezh, Russian Federation), ryazhskihav@bk.ru.

Alevtina V. Keller, DSc (Math), Docent, Professor at the Department of Applied Mathematics and Mechanics, Voronezh State Technical University (Voronezh, Russian Federation), alevtinak@inbox.ru.

Alexey V. Khorvat, PhD (Techn), Deputy Chief Scientific Officer of the Scientific Research Center, Military Educational and Scientific Center of the Air Force "N. E. Zhukovsky and Y. A. Gagarin Air Force Academy" (Voronezh, Russian Federation), alexey-khorvat@yandex.ru.

Andrey S. Vikulin, PhD (Techn), Adjunct Scientific Officer of the Scientific Research Center, Military Educational and Scientific Center of the Air Force "N. E. Zhukovsky and Y. A. Gagarin Air Force Academy" (Voronezh, Russian Federation), mmiler5472@yandex.ru.

Victor I. Ryazhskih, DSc (Techn), Full Professor, Head of the Department of Applied Mathematics and Mechanics, Voronezh State Technical University (Voronezh, Russian Federation), ryazhskih_vi@mail.ru.

Received Mart 1, 2021.

УДК 612.383

DOI: $10.14529 /$ jcem210106

\section{ИЗОТЕРМИЧЕСКИЙ МАССООБМЕН В ГРАНУЛАХ НЕОДНОРОДНО-ПОРИСТОГО АДСОРБЕНТА С ПОСЛЕДОВАТЕЛЬНЫМ МАКРО- И МИКРОДИФФУЗИОННЫМ МЕХАНИЗМОМ ПЕРЕНОСА}
А. В. Ряюских,
В. И. Ряжских

В формате 1-D сформулирована задача нестационарного изотермического локального распределения диффундирующего одновидового вещества в последовательно расположенных осесимметричных сферических областях гранулы с разной проницаемостью макро-и микропор. Начально-краевая задача для системы дифференциальных уравнений параболического типа с граничным условием первого рода на внешней границе гранулы и четвертого рода на границе сопряжения областей проинтегрирована численно. Вычислительный эксперимент продемонстрировал влияние проницаемости областей и дислокации границы между ними на кинетику транспортирования вещества.

Ключевые слова: массообмен; гранулы адсорбента; неоднородность; дифбузия. 


\section{Литература}

1. Inglezakis, V. J. Variable Diffusivity Homogeneous Surface Diffusion Model and Analysis of Merits and Fallacies of Simplified Adsorption Kinetics Equations V. J. Inglezakis, M. M. Fyrillas, J. Park // Journal of Hazardous Materials. - 2018. V. 367. - P. 224-245.

2. Tien C. Introductions to Adsorption: Basic, Analysis and Applications / C. Tien.-N. Y.: Elsevier, 2018.

3. Suzuki M. Adsorption Engineering / M. Suzuki. - Tokyo: Kodansha Ltd, 1990.

4. Toth J. Adsorption: Theory, Modeling, and Analysis / J. Toth. - N. Y.: Marcel Dekker, 2001.

5. Tovbin Y. K. The Molecular Theory of Adsorption in Porous Solid / Y. K. Tovbin. N. Y.: CRC Press, 2017.

6. Tien C. Adsorption Calculations and Modeling / C. Tien. - Boston: ButterHeinemann, 1994.

Ряжских Александр Викторович, кандидат физико-математических наук, дочент, доцент кафедры прикладной математики и механики, Воронежский государственный технический университет (г. Воронеж, Российская Федерачия), ryazhskihav@bk.ru.

Келлер Алевтина Викторовна, доктор физико-математических наук, доиент, профессор кафедры прикладной математики и механики, Воронежский государственный технический университет (г. Воронеж, Российская Федерачия), alevtinak@inbox.ru

Хорват Алексей Владимирович, кандидат технических наук, заместитель начальника отдела научно-исследовательского центра, Военный учебно-научный центр Военно-воздушньх сил «Военно-воздушная академия имени профессора Н. Е. Жуковского и Ю. А. Гагарина» (г. Воронеж, Российская Федераиия), аlехеуkhorvat@yandex.ru.

Викулин Андрей Сергеевич, адгюнкт научно-исследовательского иентра, Военный учебно-научный чентр Военно-воздушных сил «Военно-воздушная академия имени профессора Н. Е. Жуковского и Ю. А. Гагарина» (г. Воронеж, Российскал Федерачия), mmiler5472@yandex.ru.

Ряжских Виктор Иванович, доктор технических наук, профессор, зав. кафедрой прикладной математики и механики, Воронежский государственный технический университет (г. Воронеж, Российская Федераиия), ryazhskih_vi@mail.ru.

Поступила в редакцию 1 марта 2021 г. 